J. Great Lakes Res. 33 (Special Issue 3):305-318

Internat. Assoc. Great Lakes Res., 2007

\title{
Breeding Bird Communities Across an Upland Disturbance Gradient in the Western Lake Superior Region
}

\author{
Christina Miller1,2, $†$, Gerald J. Niemi*,1,2, JoAnn M. Hanowski', and Ronald R. Regal ${ }^{3}$ \\ ${ }^{1}$ Natural Resources Research Institute \\ University of Minnesota \\ 5031 Miller Trunk Highway \\ Duluth, Minnesota 55811-1442 \\ ${ }^{2}$ Department of Biology and ${ }^{3}$ Department of Mathematics and Statistics \\ University of Minnesota \\ 1049 University Drive \\ Duluth, Minnesota 55812
}

\begin{abstract}
Upland breeding bird communities were sampled from 225 points in 15 survey routes in the coastal region of western Lake Superior to examine relationships to human land use. Eighty-four species were detected and 50 were abundant enough to be included in data analysis. Monotonic quadratic regression models were constructed for these 50 species by using species counts as the dependent variable and the proportion of human conversion of the landscape (residential, agriculture, and commercial/industrial land uses) within each study area as the independent variable. Twenty-seven bird species had significant regressions $(P<0.05), 18$ of which generally avoided areas developed by humans and 9 of which were attracted to development. Detrended correspondence analysis using counts of these 27 bird species was used to investigate multivariate, community responses to development. The first DCA axis was interpreted as a gradient from urban avoiding to urban exploiting bird species and was strongly correlated with land cover variables related to human development. Our results advance the idea that breeding bird communities can be used as indicators of ecological condition and can diagnose potential causes for changes in these conditions. Further, our study points out the usefulness of bird monitoring data in regional planning efforts that incorporate goals for maintaining native biological diversity.
\end{abstract}

INDEX WORDS: Great Lakes, birds, coastal, disturbance, agriculture, urbanization, gradient.

\section{INTRODUCTION}

Habitat alteration and conversion in forested landscapes trigger substantial changes to the distribution and abundance of Neotropical migrants associated with forests (Ambuel and Temple 1982, Niemi et al. 1995, O'Connell et al. 1998). Such changes often result in increased fragmentation, creating a landscape matrix with more edge habitat, fewer large forest patches, and ultimately, greater nest predation and parasitism rates (Wilcove 1985, Temple and Cary 1988, Bolger et al. 1997, Pearson and Niemi 2000, Robinson and Robinson 2001).

\footnotetext{
*Corresponding author. E-mail: gniemi@d.umn.edu

${ }^{\dagger}$ Present address: North Hennepin Community College, 7411 85th Avenue North, Brooklyn Park, MN 55445, 651.286.7465, f 651.286.7532.

E-mail: millerchristiem@yahoo.com
}

Residential and commercial development adjacent to relatively large forest patches is related to decreased abundance of many Neotropical migrant species (Friesen et al. 1995, Nilon et al. 1995, Mancke and Gavin 2000). Landscape scale studies are needed to guide conservation and management of bird communities in regions where urbanization is the major cause of habitat loss (Allen and O'Conner 2000).

Medley et al. (1995) found that habitat change along an urban gradient resulted in small, edgedominated forests surrounded by urban development. Analyses of urban landscapes have shown declines in Neotropical migrant abundance (Allen and O'Connor 2000, Kluza et al. 2000) and increases in avian diversity and biomass at moderate levels of development (Blair 1996). However, in 
highly urbanized landscapes, bird communities are species-poor and often dominated by generalists, many of which are exotics such as the European starling (Sturnus vulgaris), house sparrow (Passer domesticus), and rock dove (Columba livia) (Jokimaki and Suhonen 1993, Pierre et al. 2000). Understanding how urbanization affects species assemblages at the landscape scale is increasingly important as urban development continues to replace and fragment forests in North America and elsewhere.

Bird communities in coastal regions of the U.S. are particularly vulnerable to habitat loss and alteration by human development because of the historical colonization of these areas by humans (Bolger et al. 1997, Niemi et al. 2004). The objective of this study was to examine the effects of residential, industrial, and agricultural land conversion on breeding bird species abundance in the coastal region of western Lake Superior using a natural experimental design. This coastal region of the U.S. Great Lakes has some areas of undeveloped lands and extensive areas dominated by development. Moreover, the region is continuing to see increased change, especially from residential and commercial development (Wolter et al. 2006).

\section{METHODS}

\section{Study Region}

The western Lake Superior coastal region (defined as land within $1 \mathrm{~km}$ of the shoreline) is primarily forested with moderate population centers in Duluth, MN, Superior, WI (collective population about 150,000), and Ashland, WI (population about 9,000 ). Our study area was about $800 \mathrm{~km}^{2}$ and included approximately $450 \mathrm{~km}$ of shoreline extending from Duluth, MN eastward to Ashland, WI. This region was divided into watersheds, where the area within $1 \mathrm{~km}$ of the shoreline of each watershed (hereafter referred to as a segment shed, Johnston et al. 2007) was used to sample the study region along the disturbance gradient.

\section{Disturbance Gradient}

Land cover classes from the National Land Cover Data (NLCD) classification scheme (Vogelmann et al. 2001) were used to derive the disturbance gradient. Sixteen of the NLCD cover classes were described as either "undeveloped" (i.e., not permanently changed by anthropogenic activity) or "developed" (Table 1) and were used to calculate the proportion of developed land per segment shed. We used a stratified random sample to select 15 segment sheds with varying proportions of developed and undeveloped land cover from the study region. Three segment sheds were selected from each of five proportional categories of development (0-20\%, 21-40\%, 41-60\%, 61-80\%, and 80-100\% developed).

\section{Breeding Bird Sampling}

We sampled each segment shed with survey routes consisting of 1510 -minute point counts. Point count locations were placed a minimum of $500 \mathrm{~m}$ apart and along secondary (or smaller) roads (Hanowski and Niemi 1995). Points were surveyed between 0.5 hour before and 4.0 hours after sunrise. All birds seen or heard at an unlimited distance were recorded; however most observations were made within a $100 \mathrm{~m}$ radius. Flyovers were recorded but not included in data analyses unless known to have left from within the area of the point being sampled. Counts were made in clear weather (i.e., no precipitation and calm winds). Each route was sampled once during the breeding season.

\section{Land Cover Resampling}

Some segment sheds were too small to fully include all 15 points along a route. Hence, we resampled land cover classes within each survey route in a geographic information system (GIS) using a 250 $m$ radius buffer round each of the 15 points ( 45 $\mathrm{km}^{2}$ ). Land cover classes were summarized for each route in the same manner used to determine the initial disturbance gradient.

\section{Data Analysis}

We used regression analysis to explore the relationship between counts of bird species and land cover proportions. Because relationships between bird abundances and development are not necessarily linear nor with a constant variance, we used monotone quadratic regression and Box-Cox transformation (SAS Institute 1999). Using a monotone function allowed for the detection of generally increasing or decreasing nonlinear relationships. A Box-Cox transformation of the dependent variable, bird counts, reduced the effects of non-normality and unequal variances observed. To make objective comparisons among multiple species, we used the TRANSREG procedure in 
TABLE 1. National land cover data classification system definitions and descriptions of cover classes found in the study region. Percentages of each cover class were summed for each study area to determine the percent developed area in each study area $(n=15)$. Descriptions are based on \% pixel coverage. Pixels have $30 \mathrm{~m} \times 30 \mathrm{~m}$ resolution.

\begin{tabular}{|c|c|c|}
\hline Cover class & Definition & Description \\
\hline Commercial/industrial & $\begin{array}{l}\text { 30-100\% cover, highly developed land such as roads, railroads and } \\
\text { other infrastructure not classified as high intensity residential. }\end{array}$ & Developed \\
\hline Grassland/herbaceous & $\begin{array}{l}75-100 \% \text { herbaceous grasses and forbs, not subjected to } \\
\text { intense management }\end{array}$ & Developed \\
\hline High intensity residential & $\begin{array}{l}80-100 \% \text { cover of constructed materials (i.e., asphalt, concrete } \\
\text { buildings), vegetation } \leq 20 \% \text { cover }\end{array}$ & Developed \\
\hline Low intensity residential & $30-80 \%$ cover of constructed materials, vegetation $20-70 \%$ cover & Developed \\
\hline Pasture/hay & Areas planted for livestock grazing or the production of seed or hay crops & Developed \\
\hline Quarry/strip mine/gravel pit & Extractive mining activities & Developed \\
\hline Row crops & Crops, such as corn, soybeans, vegetables, and cotton. & Developed \\
\hline Bare rock/sand/clay & Perennially barren areas (i.e., bedrock, beaches, etc.) & Undeveloped \\
\hline Deciduous forest & $\geq 75 \%$ tree species deciduous & Undeveloped \\
\hline Evergreen forest & $\geq 75 \%$ trees species evergreen & Undeveloped \\
\hline Mixed forest & $\begin{array}{l}\text { Areas dominated by trees where neither deciduous nor evergreen } \\
\text { species represent more than } 75 \% \text { of cover }\end{array}$ & Undeveloped \\
\hline Open water & $\geq 25 \%$ open water & Undeveloped \\
\hline Transitional & $\begin{array}{l}\leq 25 \% \text { sparse vegetation cover (i.e., clear cuts, agricultural forest } \\
\text { edge, etc.) }\end{array}$ & Undeveloped \\
\hline Herbaceous wetland & $\begin{array}{l}75-100 \% \text { perennial herbaceous vegetation cover; soil or substrate is } \\
\text { eriodically saturated with or covered with water. }\end{array}$ & Undeveloped \\
\hline Woody wetland & $\begin{array}{l}25-100 \% \text { forest or shrubland cover and the soil or substrate is } \\
\text { periodically saturated with or covered with water. }\end{array}$ & Undeveloped \\
\hline
\end{tabular}

SAS to automatically transform the dependent variable and fit a monotone regression model for each species (SAS Institute 1999). Bird species observed in five or more study areas were included in these analyses and a constant value of one was added to each abundance count to avoid taking the log of zero.

To fit the monotone response with a Box-Cox transformation, we used the MSPLINE and BoxCox options in SAS procedure TRANSREG. The SAS output file gave values for $b_{0}$ and $b_{1}$ for the monotone regression model written as a linear combination

$$
\mathrm{T} y=\mathrm{b}_{\mathrm{o}}+\mathrm{b}_{1} \mathrm{~T} x
$$

where $\mathrm{T} y$ is the transformed fitted regression value. $\mathrm{T} x$ is given by the expression

$$
\mathrm{T} x=\mathrm{a}_{\mathrm{o}}(1-x)^{2}+2 \mathrm{a}_{1} x(1-x)+\mathrm{a}_{2} x^{2}
$$

where $x$ is the independent variable (i.e., percent development) and $\mathrm{a}_{0}, \mathrm{a}_{1}$, and $\mathrm{a}_{2}$ are coefficients computed by SAS. These coefficients are given in the output by the DETAILS option in the SAS model statement. Combining Equations 1 and 2 gives a quadratic fit to Ty (Equation 3) where the numerical values for coefficients $\mathrm{a}, \mathrm{b}$, and $\mathrm{c}$ are constants in the fit monotone regression model for each species.

$$
\mathrm{T} y=\mathrm{a} x^{2}+\mathrm{b} x+\mathrm{c}
$$

We used detrended correspondence analysis (DCA, using the program PC-ORD) on the matrix of 27 bird species counts to analyze associations between 
TABLE 2. Cover class percentages used in detrended correspondence analysis. First column is the total percent developed area for each study area (not included in DCA). Study areas are ordered by increasing amount of development.

\begin{tabular}{|c|c|c|c|c|c|c|c|c|c|c|}
\hline Site & $\begin{array}{c}\text { Developed } \\
\text { area }\end{array}$ & $\begin{array}{l}\text { Residential } \\
\text { development }\end{array}$ & $\begin{array}{l}\text { Commercial/ } \\
\text { industrial } \\
\text { development }\end{array}$ & Pasture & $\begin{array}{l}\text { Row } \\
\text { crop }\end{array}$ & $\begin{array}{c}\text { Urban } \\
\text { grass }\end{array}$ & $\begin{array}{l}\text { Deciduous } \\
\text { forest }\end{array}$ & $\begin{array}{l}\text { Evergreen } \\
\text { forest }\end{array}$ & $\begin{array}{l}\text { Mixed } \\
\text { forest }\end{array}$ & Wetland \\
\hline Cornucopia 1 & 8 & 0 & 0 & 5 & 3 & 0 & 25 & 22 & 41 & 1 \\
\hline Cornucopia 2 & 19 & 0 & 0 & 10 & 9 & 0 & 32 & 21 & 28 & 0 \\
\hline Bayfield 1 & 22 & 3 & 3 & 4 & 6 & 6 & 28 & 24 & 25 & 0 \\
\hline Bayfield 3 & 28 & 0 & 2 & 16 & 10 & 0 & 37 & 14 & 21 & 1 \\
\hline East Duluth 1 & 28 & 3 & 13 & 8 & 3 & 0 & 42 & 6 & 24 & 0 \\
\hline Washburn 1 & 31 & 1 & 0 & 18 & 12 & 0 & 24 & 28 & 15 & 1 \\
\hline Bayfield 2 & 49 & 13 & 6 & 11 & 10 & 8 & 35 & 4 & 12 & 0 \\
\hline Washburn 2 & 59 & 34 & 9 & 5 & 2 & 8 & 29 & 6 & 7 & 0 \\
\hline East Duluth 2 & 59 & 49 & 2 & 1 & 1 & 6 & 27 & 5 & 7 & 2 \\
\hline Superior 3 & 61 & 32 & 15 & 1 & 8 & 5 & 30 & 1 & 2 & 6 \\
\hline Ashland & 68 & 35 & 10 & 3 & 18 & 1 & 21 & 5 & 6 & 0 \\
\hline Superior 1 & 90 & 23 & 56 & 0 & 0 & 9 & 8 & 0 & 1 & 1 \\
\hline Superior 2 & 91 & 57 & 25 & 1 & 0 & 8 & 7 & 0 & 1 & 0 \\
\hline Central Duluth & 95 & 82 & 11 & 0 & 0 & 1 & 5 & 0 & 1 & 0 \\
\hline West Duluth & 95 & 33 & 55 & 0 & 1 & 4 & 4 & 0 & 1 & 0 \\
\hline Mean & 54 & 24 & 14 & 6 & 6 & 4 & 37 & 9 & 13 & 0.8 \\
\hline
\end{tabular}

bird assemblages and land use (McCune and Mefford 1999). The nine land cover classes having minimum of $5 \%$ coverage for at least one of the survey route were used as overlay vectors on the ordination diagram (Table 2). Herbaceous and woody wetland classes comprised relatively small amounts of area and were combined into one wetland class. High and low intensity residential development classes were combined into one class to focus on the overall contribution of residential development.

\section{RESULTS}

\section{Land Use in Study Areas}

Forests (e.g., deciduous, coniferous, and mixed forest combined) comprised $45 \%$ of the total area, urban development (e.g., residential and commercial development) 39\%, and agricultural development (e.g., pasture and row crop) $11 \%$. Agricultural development was concentrated in the eastern region of the study; such as in Bayfield 2, Bayfield 3, Washburn 1, and Ashland survey routes (Table 2). Developed land area among the study areas ranged from $8.5 \%$ in Cornucopia 1 to $95 \%$ in West Duluth (Table 2). In general, most urban, residential, and industrial areas were found in the western portion of the study region.

\section{Bird and Land Use Relationships}

A total of 84 species were identified during the 2001 breeding season. Fifty species were present at five or more study areas and included in the regression analysis (Table 3 ). Of the 50 species included in the regression analysis, 27 had significant regressions $(P<0.05$; Table 4$)$ and, hence, 23 species had a neutral response to the disturbance gradient. Regression results are grouped by species association with the disturbance gradient as determined by the DCA (see below). Urban avoiders had negative relationships and urban exploiters had positive relationships with the disturbance gradient (Table 4).

Eighteen species had significant negative regressions $(P<0.05)$, and 11 of those were Neotropical migrants. Several Neotropical migrants (e.g., ovenbird [Seiurus aurocapillus], red-eyed vireo [Vireo olivaceus]) had strong negative relationships with development and relatively large $\mathrm{R}^{2}$ values (Fig. 1, Table 4). The remaining Neotropical migrants occurred at lower abundances and generally had lower $\mathrm{R}^{2}$ values (Fig. 2, Table 4). Several shortdistance migrants and resident species had negative relationships with development (Fig. 3). Among them, the white-throated sparrow (Zonotrichia alibicollis) had the largest $\mathrm{R}^{2}$ value (Table 4 ). Nine species had positive relationships with development (Figs. 4 and 5) and tended to have lower $\mathrm{R}^{2}$ values than the urban avoiders (Table 4). The Euro- 
TABLE 3. Common name, scientific name, migratory status, mean and standard error (SE) for species present at five or more study areas that were included in analyses $(n=50)$. Mean and (SE) are number of each species observed in the 15 study areas (total for 225 point counts). Migratory status is based on information from the forest birds of Minnesota website (FBM 2002); $N=$ Neotropical migrant, $S D=$ short distance migrant, $R=$ resident species. Species with significant $(p<0.05)$ relationships with the distribution gradient are identified in bold. Those not in bold are excluded from further analyses.

\begin{tabular}{|c|c|c|c|c|}
\hline Common name & Scientific name & Migratory status & Species code & Mean(SE) \\
\hline Herring Gull & Larus argentatus & SD & herg & $1.60(3.60)$ \\
\hline Ring-billed Gulla & Larus delawarensis & SD & rbgu & $9.80(12.54)$ \\
\hline Killdeer & Charadrius vociferus & SD & kill & $0.80(1.66)$ \\
\hline Rock Dovea & Columba livia & $\mathrm{R}$ & rodo & $5.53(7.14)$ \\
\hline Mourning Dovea & Zenaida macroura & SD & modo & $3.20(2.93)$ \\
\hline Downy Woodpecker & Picoides pubescens & $\mathbf{R}$ & dowo & $0.80(1.52)$ \\
\hline Yellow-bellied Sapsuckera & Sphyrapicus varius & SD & ybsa & $1.20(1.74)$ \\
\hline Yellow-shafted Flicker & Colaptes auratus & SD & ysfl & $0.60(0.83)$ \\
\hline Chimney Swift ${ }^{\mathrm{a}}$ & Chaetura pelagica & $\mathrm{N}$ & chsw & $1.93(3.03)$ \\
\hline Alder Flycatcher & Empidonax alnorum & $\mathbf{N}$ & alfl & $1.67(2.38)$ \\
\hline Great Crested Flycatchera & Myiarchus crinitus & $\mathrm{N}$ & gcfl & $1.40(1.55)$ \\
\hline Eastern Phoebe & Sayornis phoebe & $\mathrm{SD}$ & eaph & $1.27(1.83)$ \\
\hline Eastern Wood-Pewee & Contopus virens & $\mathbf{N}$ & eawp & $0.67(0.98)$ \\
\hline Least Flycatcher ${ }^{\mathrm{a}}$ & Empidonax minimus & $\mathrm{N}$ & lefl & $1.33(1.59)$ \\
\hline Blue Jaya & Cyanocitta cristata & $\mathrm{R}$ & blja & $5.93(3.88)$ \\
\hline American Crow & Corvus brachyrhynchos & SD & amcr & $24.93(9.35)$ \\
\hline European Starlinga & Sturnus vulgaris & $\mathrm{R}$ & eust & $20.27(20.10)$ \\
\hline Brown-headed Cowbirda & Molothrus ater & SD & bhco & $1.13(1.46)$ \\
\hline Red-winged Blackbird & Agelaius phoeniceus & SD & rwbl & $8.80(9.36)$ \\
\hline Common Gracklea & Quiscalus quiscula & SD & $\operatorname{cog} r$ & $7.67(6.44)$ \\
\hline American Goldfinch & Carduelis tristis & SD & amgo & $6.87(7.29)$ \\
\hline Savannah Sparrowa & Passerculus sandwichensis & SD & savs & $1.20(1.82)$ \\
\hline White-throated Sparrowa & Zonotrichia albicollis & SD & wtsp & $6.27(6.94)$ \\
\hline Chipping Sparrow & Spizella passerina & SD & chsp & $9.40(4.34)$ \\
\hline Clay-colored Sparrow & Spizella pallida & SD & $\operatorname{ccsp}$ & $1.80(3.00)$ \\
\hline Song Sparrow & Melospiza melodia & SD & sosp & $19.27(7.37)$ \\
\hline Northern Cardinal & Cardinalis cardinalis & $\mathbf{R}$ & noca & $0.73(1.16)$ \\
\hline Rose-breasted Grosbeak & Pheucticus ludovicianus & $\mathbf{N}$ & rbgr & $0.93(1.53)$ \\
\hline Cedar Waxwinga & Bombycilla cedrorum & SD & cedw & $7.07(5.54)$ \\
\hline Red-eyed Vireo ${ }^{\mathrm{a}}$ & Vireo olivaceus & $\mathrm{N}$ & revi & $20.07(12.23)$ \\
\hline Black-and-white Warblera & Mniotilta varia & $\mathrm{N}$ & baww & $2.60(3.44)$ \\
\hline Nashville Warbler & Vermivora ruficapilla & $\mathbf{N}$ & nawa & $4.47(5.72)$ \\
\hline Yellow Warbler ${ }^{a}$ & Dendroica petechia & $\mathbf{N}$ & ywar & $6.67(7.33)$ \\
\hline Myrtle Warblera & Dendroica coronata & SD & mywa & $1.47(2.23)$ \\
\hline Chestnut-sided Warblera & Dendroica pensylvanica & $\mathrm{N}$ & cswa & $10.53(8.31)$ \\
\hline Blackburnian Warblera & Dendroica fusca & $\mathrm{N}$ & blbw & $1.20(1.97)$ \\
\hline Black-throated Green Warblera & Dendroica virens & $\mathrm{N}$ & btnw & $8.73(10.34)$ \\
\hline Pine Warbler & Dendroica pinus & SD & piwa & $0.53(0.92)$ \\
\hline Ovenbird $^{\mathrm{a}}$ & Seiurus aurocapillus & $\mathrm{N}$ & oven & $17.87(17.14)$ \\
\hline Mourning Warbler ${ }^{\mathrm{a}}$ & Oporornis philadelphia & $\mathrm{N}$ & mowa & $2.07(2.79)$ \\
\hline Common Yellowthroat & Geothlypis trichas & $\mathbf{N}$ & coye & $8.53(9.74)$ \\
\hline American Redstart ${ }^{\mathrm{a}}$ & Setophaga ruticilla & $\mathrm{N}$ & amre & $12.07(9.07)$ \\
\hline House Sparrowa & Passer domesticus & $\mathrm{R}$ & hosp & $9.67(13.56)$ \\
\hline Gray Catbird & Dumetella carolinensis & $\mathbf{N}$ & grca & $2.47(2.61)$ \\
\hline House Wren & Troglodytes aedon & $\mathbf{N}$ & howr & $2.80(3.00)$ \\
\hline Red-breasted Nuthatcha & Sitta canadensis & $\mathbf{R}$ & rbnu & $1.93(2.05)$ \\
\hline Black-capped Chickadee & Poecile atricapillus & $\mathbf{R}$ & bech & $14.47(8.00)$ \\
\hline Veerya & Catharus fuscescens & $\mathrm{N}$ & veer & $7.60(6.65)$ \\
\hline Hermit Thrush & Catharus guttatus & SD & heth & $0.67(1.18)$ \\
\hline American Robin & Turdus migratorius & SD & amro & $26.60(7.14)$ \\
\hline
\end{tabular}

a Species with significant regression results $(\alpha=0.05)$ 
TABLE 4. $R^{2}$ values, lambdas chosen by Box-Cox transformation, and monotone spline model coefficients for 27 species with significant regression results grouped according to associations with development as determined by DCA analysis. Coefficients are listed for regression Equations 1 and 2 (see Methods). $d f=14$

\begin{tabular}{|c|c|c|c|c|c|c|c|}
\hline & $\mathrm{R} 2$ & $\lambda$ & $a_{0}$ & $\mathrm{~A}_{1}$ & $\mathrm{a}_{2}$ & $\mathrm{~b}_{0}$ & $\mathrm{~b}_{1}$ \\
\hline \multicolumn{8}{|l|}{ Urban Avoiders } \\
\hline Yellow-bellied Sapsucker & $-0.58 * *$ & -0.9 & 2.9 & 63.4 & 91.4 & 2.4 & 0.0 \\
\hline Great Crested Flycatcher & $-0.59 * *$ & -0.4 & 13.7 & 41.4 & 97.7 & 3.1 & 0.0 \\
\hline Eastern Phoebe & $-0.49 * *$ & -0.8 & 23.7 & 23.7 & 101.6 & 2.6 & 0.0 \\
\hline Least Flycatcher & $-0.51 *$ & -0.5 & 16.0 & 37.2 & 98.7 & 2.8 & 0.0 \\
\hline Blue Jay & $-0.42 * *$ & 0.7 & 23.7 & 23.7 & 101.6 & 11.0 & -0.1 \\
\hline White-throated Sparrow & $-0.86 * * *$ & 0.0 & 10.3 & 48.0 & 96.0 & 14.6 & -0.2 \\
\hline Cedar Waxwing & $-0.37 *$ & 0.3 & 23.7 & 23.7 & 101.6 & 14.5 & -0.1 \\
\hline Red-eyed Vireo & $-0.90 * * *$ & 0.8 & 23.7 & 23.7 & 101.6 & 42.6 & -0.4 \\
\hline Black-and-white Warbler & $-0.61 * *$ & -0.4 & 5.5 & 57.8 & 93.2 & 5.1 & -0.1 \\
\hline Myrtle Warbler & $-0.67 * *$ & -0.9 & 0.9 & 67.9 & 90.0 & 3.0 & 0.0 \\
\hline Chestnut-sided Warbler & $-0.77 * * *$ & -1.0 & -5.7 & 84.2 & 84.2 & -0.4 & 0.0 \\
\hline Blackburnian Warbler & $-0.66 * *$ & -0.9 & -3.9 & 79.5 & 85.9 & 2.3 & 0.0 \\
\hline Black-throated Green Warbler & $-0.87 * * *$ & 0.0 & 5.8 & 57.1 & 93.4 & 18.2 & -0.2 \\
\hline Ovenbird & $-0.91 * * *$ & 0.3 & 14.2 & 40.6 & 97.9 & 41.1 & -0.4 \\
\hline Mourning Warbler & $-0.82 * * *$ & -0.4 & -1.7 & 74.1 & 87.9 & 4.6 & -0.1 \\
\hline American Redstart & $-0.81 * * *$ & 0.4 & 23.7 & 23.7 & 101.6 & 27.8 & -0.3 \\
\hline Red-breasted Nuthatch & $-0.46^{*}$ & 0.0 & 12.1 & 44.5 & 96.9 & 4.0 & 0.0 \\
\hline Veery & $-0.66 * * *$ & 0.2 & 23.7 & 23.7 & 101.6 & 17.6 & -0.2 \\
\hline \multicolumn{8}{|l|}{ Urban exploiters } \\
\hline Ring-billed Gull & $0.75^{* * *}$ & -0.2 & 12.1 & 44.6 & 96.9 & 0.7 & 0.2 \\
\hline Rock Dove & $0.64 * * *$ & -0.1 & 23.7 & 23.7 & 101.6 & -2.3 & 0.1 \\
\hline Mourning Dove & $0.27 *$ & 0.0 & -5.7 & 84.2 & 84.2 & 1.5 & 0.0 \\
\hline Chimney Swift & $0.41 *$ & 0.4 & 10.5 & 47.6 & 96.1 & 24.7 & -0.2 \\
\hline European Starling & $0.83 * * *$ & 0.4 & 10.1 & 48.4 & 95.9 & -3.2 & 0.5 \\
\hline Brown-headed Cowbird & $0.34 *$ & -0.7 & -5.7 & 84.2 & 84.2 & -0.1 & 0.0 \\
\hline Common Grackle & $0.70 * * *$ & 0.4 & -5.7 & 84.2 & 84.2 & -0.9 & 0.2 \\
\hline Savannah Sparrow & $0.28^{*}$ & -1.0 & -5.7 & 84.2 & 84.2 & -0.1 & 0.0 \\
\hline House Sparrow & $0.83 * * *$ & -0.3 & 17.6 & 34.2 & 99.4 & -3.9 & 0.2 \\
\hline
\end{tabular}

*** $P<0.001 ; * * P<0.01 ; * P<0.05$

pean starling (Sturnis vulgaris) was found at a relatively high abundance and had the strongest positive relationship with development (Fig. 3). Twenty-three species had non-significant regression results. Several species, including American crow (Corvus brachyrhynchos), song sparrow (Melospiza melodia), and American robin (Turdus migratorius) had high average abundances (Table $3)$.

\section{Detrended Correspondence Analysis}

Axis 1 from the DCA explained $90 \%$ of variation in bird species counts among the survey routes (Table 5). Little variation was explained by axes 2 and 3 with coefficients of determination of 0.01 and
0.00 , respectively. Thus, the results and discussion will be limited to axis 1 .

We interpreted the first DCA axis as a gradient in bird species composition from urban avoiding species to urban exploiting species. Survey routes in urban areas (e.g., Central and West Duluth) had high scores on axis 1 while undeveloped study areas (e.g., Cornucopia 1 and 2) had low scores (Fig. 6). Species found primarily in undeveloped study areas had low axis 1 scores (urban avoiders) and those most frequently found in developed sites had high axis 1 values (urban exploiters) (Fig. 7). Residential and commercial land cover was highly positively correlated with axis 1 , while forested lands were negatively correlated with axis 1 (Fig. 7). 


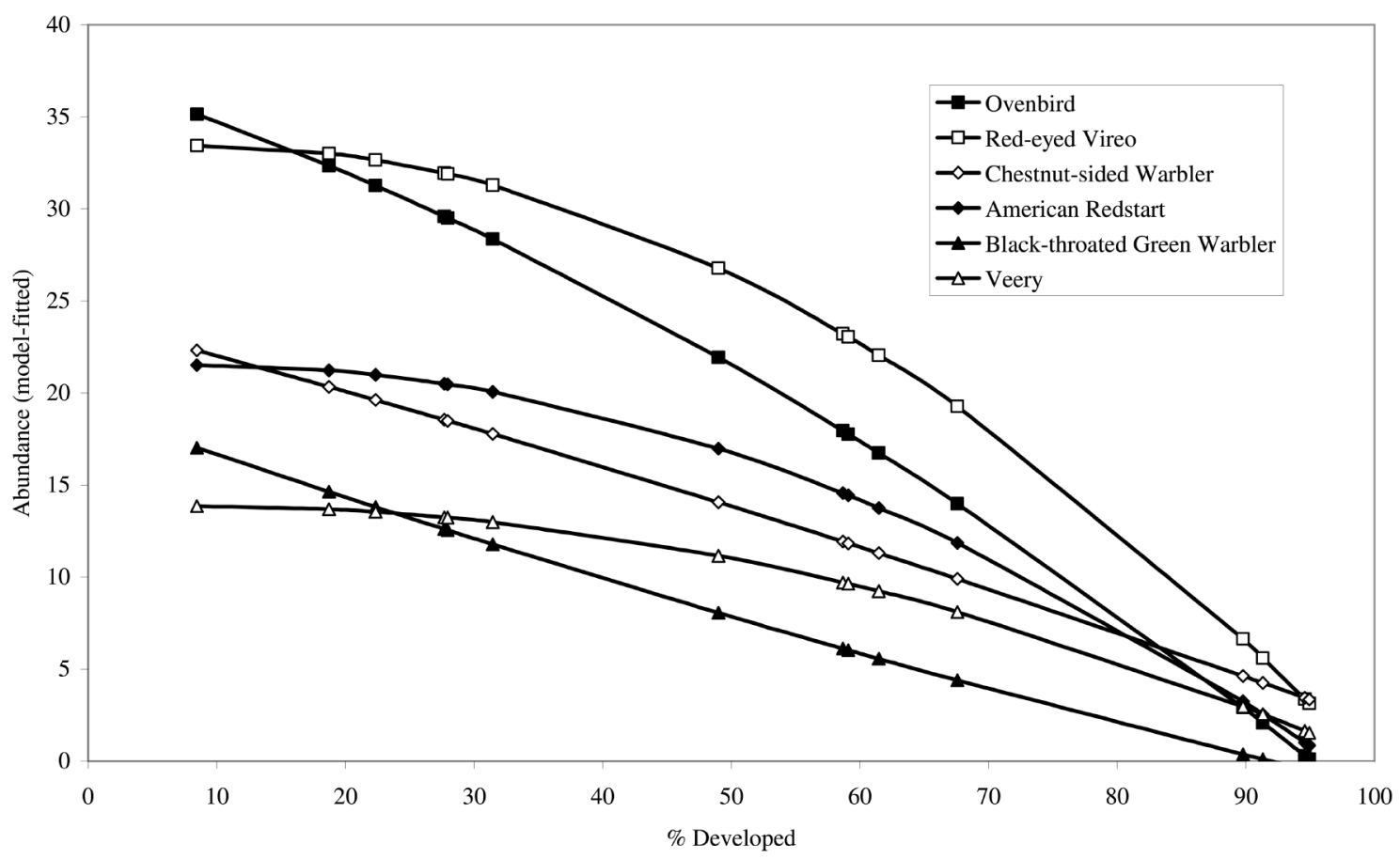

FIG. 1. Monotone spline fit regression lines for forest associated Neotropical migrants with relative abundance as the dependent variable and percent developed area for 15 study areas in the western Lake Superior region as the independent variable. Abundances not reported in original scale, but are transformed by Box-Cox transformation to satisfy normality and equality of variance assumptions.

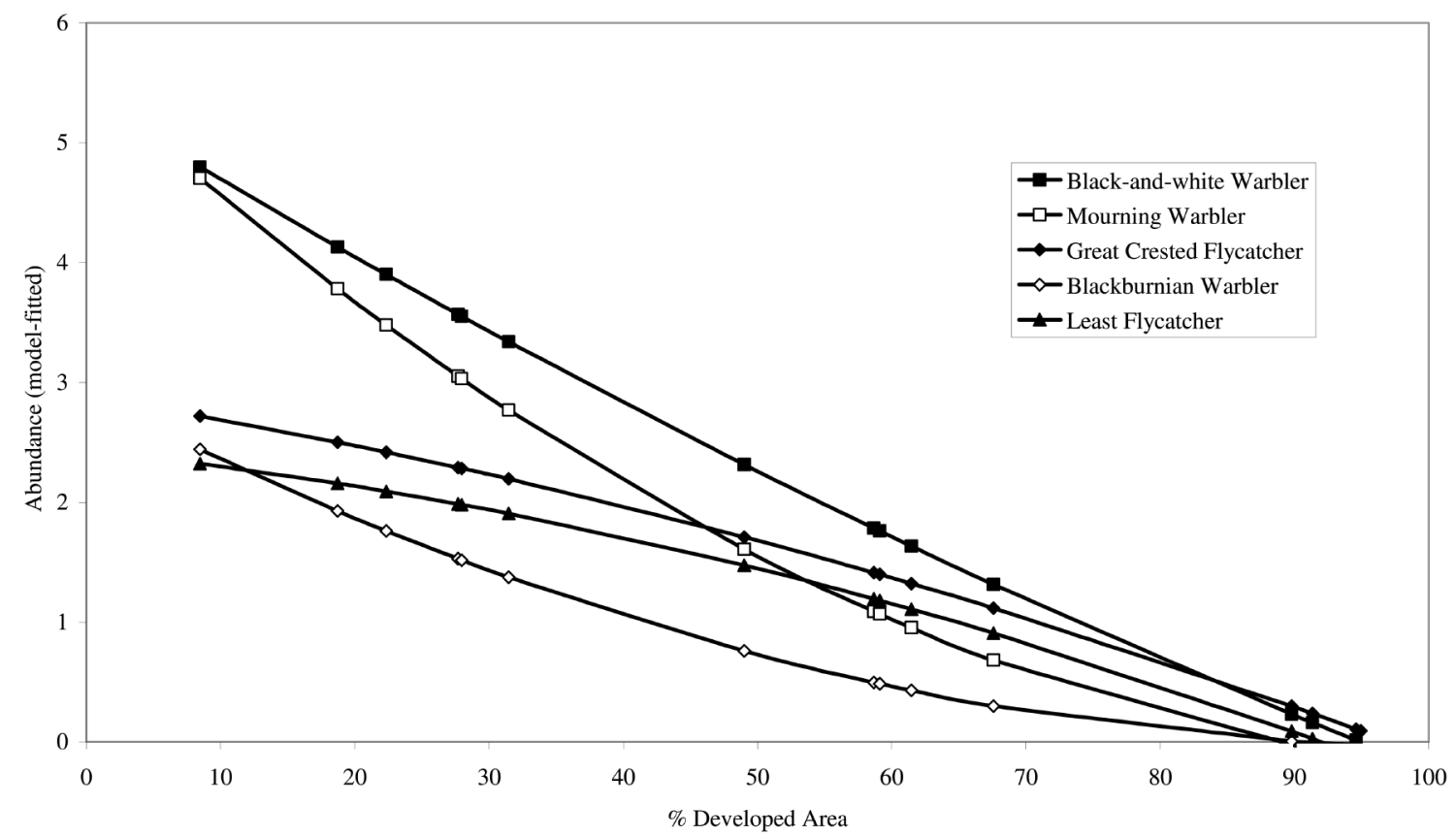

FIG. 2. Monotone spline fit regression lines for forest associated Neotropical migrants with relative abundance as the dependent variable and percent developed area for 15 study areas in the western Lake Superior region as the independent variable. Abundances not reported in original scale, but are transformed by Box-Cox transformation to satisfy normality and equality of variance assumptions 


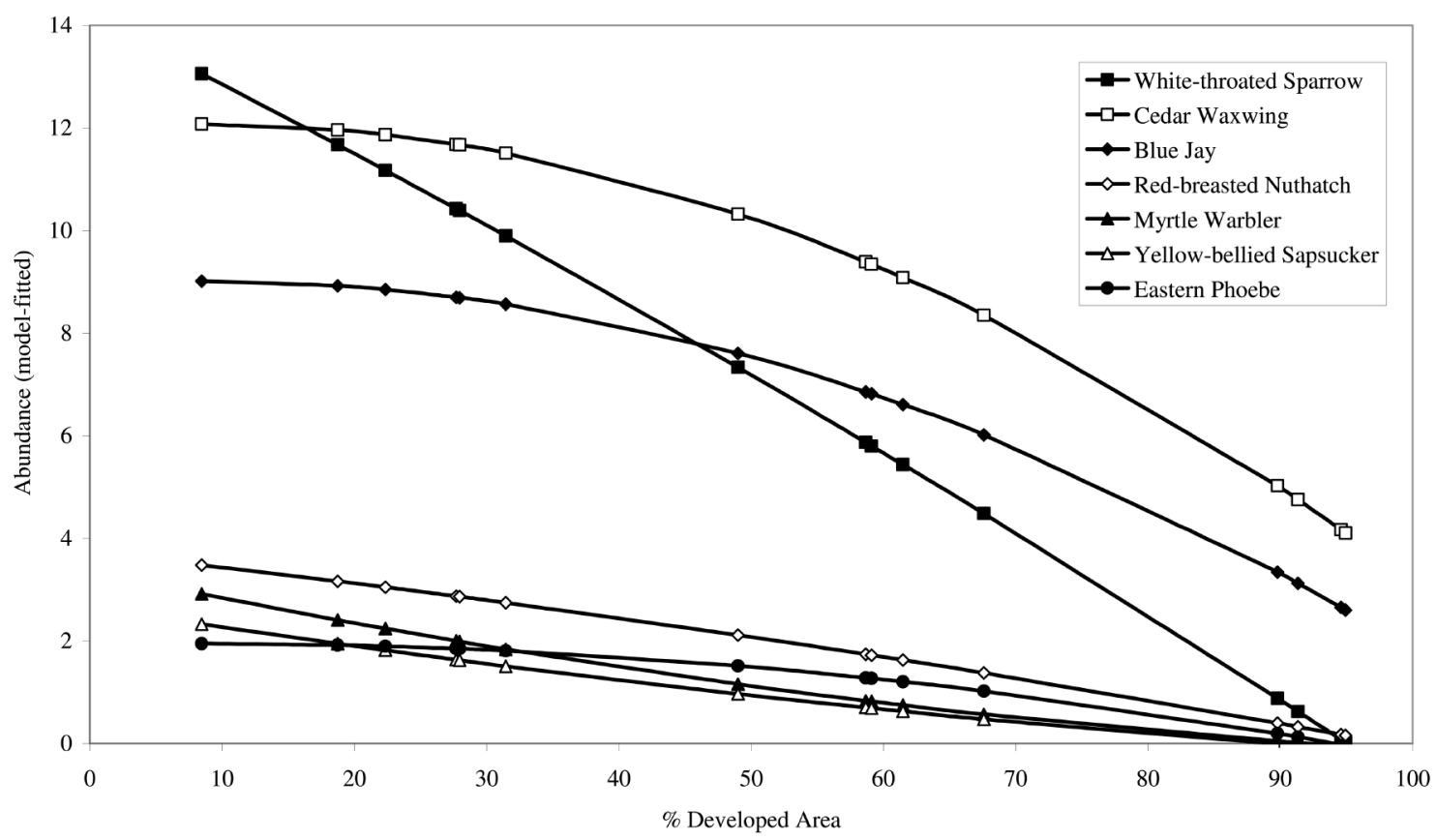

FIG. 3. Monotone spline fit regression lines for forest associated short distance migrants and resident species with relative abundance as the dependent variable and percent developed area for 15 study areas in the western Lake Superior region as the independent variable. Abundances not reported in original scale, but are transformed by BoxCox transformation to satisfy normality and equality of variance assumptions.

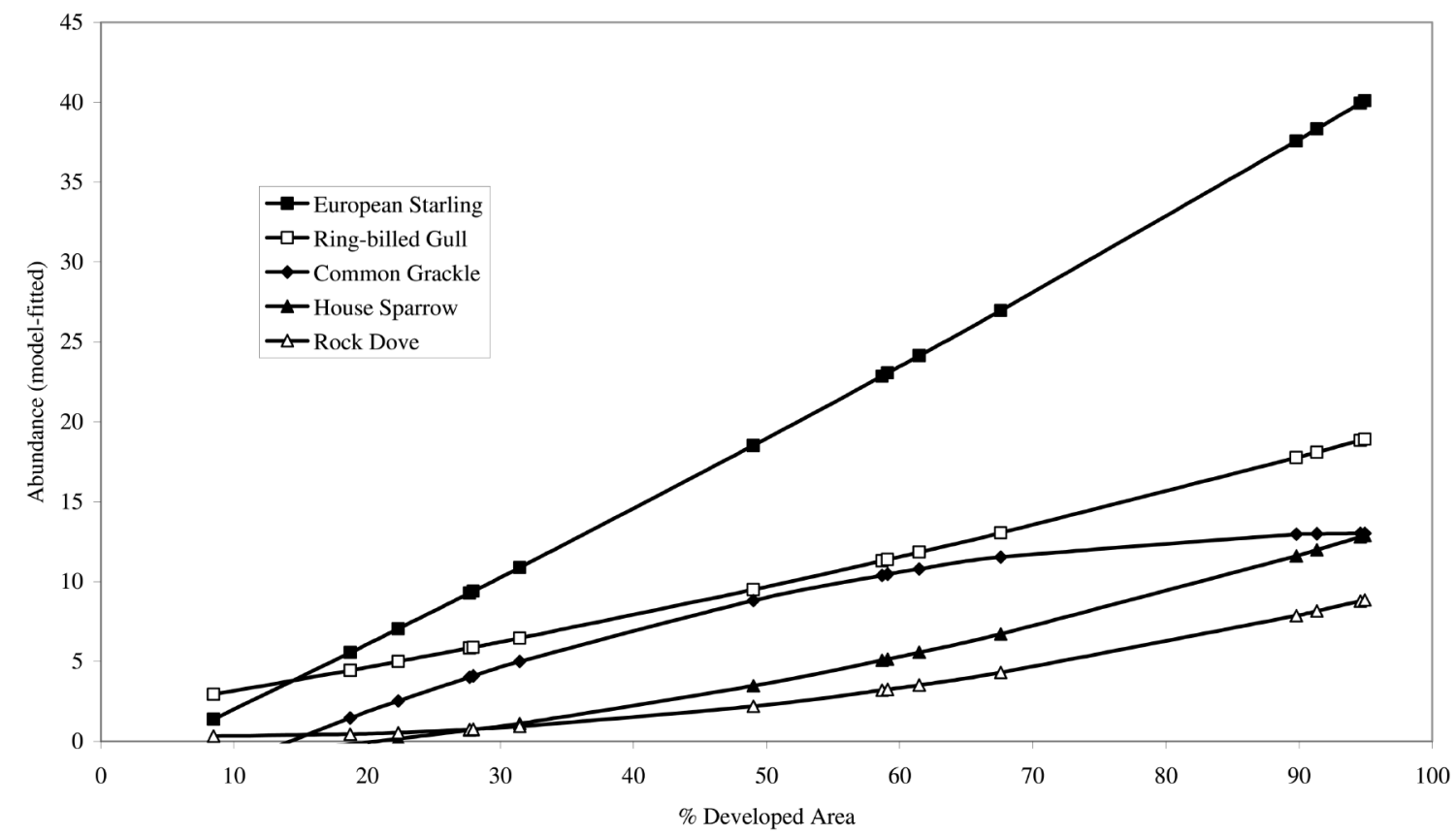

FIG. 4. Monotone spline fit regression lines for urban associated species with relative abundance as the dependent variable and percent developed area for 15 study areas in the western Lake Superior region as the independent variable. Abundances not reported in original scale, but are transformed by Box-Cox transformation to satisfy normality and equality of variance assumptions. 


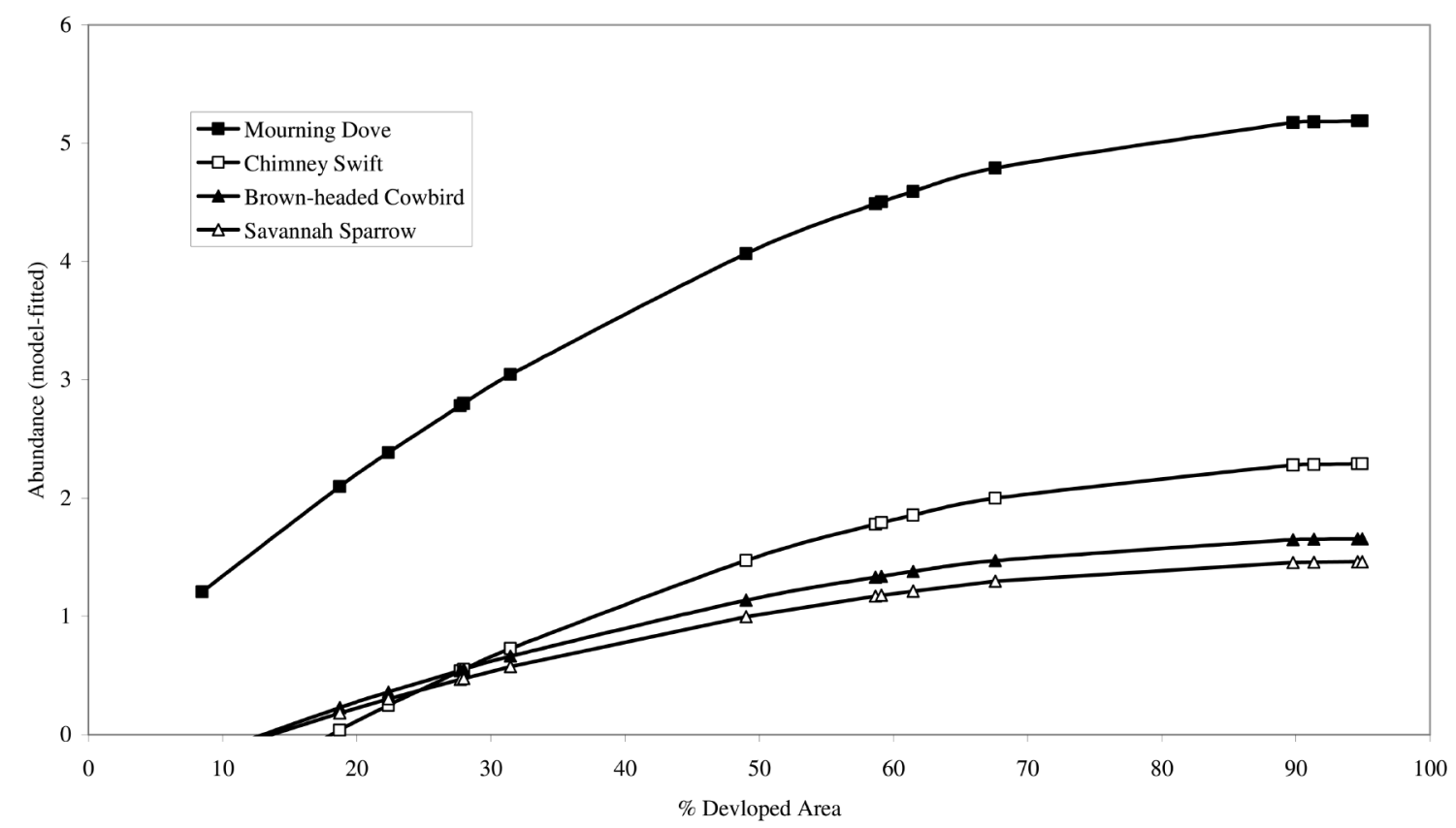

FIG. 5. Monotone spline fit regression lines for urban associated species with relative abundance as the dependent variable and percent developed area for 15 study areas in the western Lake Superior region as the independent variable. Abundances not reported in original scale, but are transformed by Box-Cox transformation to satisfy normality and equality of variance assumptions.

\section{DISCUSSION}

Neotropical migrant abundance is known to decrease with increasing human development at habitat patch (Dowd 1992, Freisen et al. 1995), landscape matrix (Bolger et al. 1997), and regional scales (Allen and O'Connor 2000, O'Connell et al. 2000). Our results are consistent with results from these studies and illustrate similar patterns for these coastal regions and for forests in the Upper Midwestern United States. Counts of bird species changed substantially among study areas along a regional disturbance gradient. The disturbance gradient was primarily influenced by changes in the landscape due to residential, urban development, but also due to agricultural and industrial land use change. Based on the relationship between bird species and the disturbance gradient, species could be grouped as either avoiders of human disturbance (positive relationship with natural land area such as forest) or exploiters of human-dominated landscapes (positive relationship with developed area such as agriculture or urban areas) (sensu Blair 1996). O'Connell et al. (1998, 2000) in their development of indices of biological integrity (IBI) using bird responses to disturbance gradients further iden- tified bird species associated with forests, agricultural areas, or urban/residential areas.

In contrast, 23 species showed no significant relationship with the disturbance gradient. Many of these species are found in a wide variety of habitats, including urban and forested or semi-forested habitats such as the downy woodpecker, yellowshafted flicker, eastern phoebe, American crow, chipping sparrow, rose-breasted grosbeak, redbreasted nuthatch, and black-capped chickadee (Cutright et al. 2006). Species such as the alder flycatcher, red-winged blackbird, American goldfinch, yellow warbler, and common yellowthroat are found in wetlands and shrub habitats which are distributed throughout forested, urban, and agricultural landscapes (Cutright et al. 2006). Several species such as killdeer, eastern wood-pewee, northern cardinal, pine warbler, and hermit thrush were uncommon and, hence, the statistical power for detecting relationships for these species may have been relatively weak.

Most bird species that avoided human-dominated areas were Neotropical migrants that use forested areas. In general, most of this region was historically forested. Although forest loss along the devel- 
TABLE 5. Pearson correlation coefficients (r) for cover classes and species for DCA axis 1. The bottom row has the eigenvalue and coefficient of determination for DCA axis 1. The coefficient of determination is equal to the proportion of variation in ordination space explained by the axis.

\begin{tabular}{|c|c|}
\hline Variable & $\begin{array}{l}\text { Pearson correlation } \\
\text { coefficients }(r)\end{array}$ \\
\hline Cover classes & DCA Axis 1 \\
\hline Residential development & 0.78 \\
\hline Commercial/industrial & 0.77 \\
\hline Urban grass & 0.47 \\
\hline Deciduous forest & -0.87 \\
\hline Mixed forest & -0.86 \\
\hline Evergreen forest & -0.78 \\
\hline Pasture & -0.71 \\
\hline Row crop & -0.44 \\
\hline Wetland & -0.12 \\
\hline \multicolumn{2}{|l|}{ Urban avoiders } \\
\hline Yellow-bellied Sapsucker & -0.60 \\
\hline Great Crested Flycatcher & -0.66 \\
\hline Eastern Phoebe & -0.39 \\
\hline Least Flycatcher & -0.68 \\
\hline White-throated Sparrow & -0.78 \\
\hline Red-eyed Vireo & -0.90 \\
\hline Black-and-white Warbler & -0.63 \\
\hline Myrtle Warbler & -0.58 \\
\hline Chestnut-sided Warbler & -0.80 \\
\hline Blackburnian Warbler & -0.60 \\
\hline Black-throated Green Warbler & -0.81 \\
\hline Ovenbird & -0.86 \\
\hline Mourning Warbler & -0.70 \\
\hline American Redstart & -0.80 \\
\hline Red-breasted Nuthatch & -0.68 \\
\hline Blue Jay & -0.60 \\
\hline Cedar Waxwing & -0.50 \\
\hline Veery & -0.58 \\
\hline \multicolumn{2}{|l|}{ Urban exploiters } \\
\hline Mourning Dove & 0.18 \\
\hline Chimney Swift & 0.23 \\
\hline Brown-headed Cowbird & 0.30 \\
\hline Common Grackle & 0.73 \\
\hline Savannah Sparrow & 0.47 \\
\hline Ring-billed Gull & 0.82 \\
\hline Rock Dove & 0.88 \\
\hline European Starling & 0.91 \\
\hline House Sparrow & 0.92 \\
\hline Eigenvalue & 0.60 \\
\hline Coefficient of determination & 0.94 \\
\hline
\end{tabular}

opment gradient can explain much of the variation in the abundance of several species, especially Neotropical migrants, other landscape and habitat features may affect these relationships and are probably not mutually exclusive. For example, wetland loss in the coastal region of the Great Lakes has also been extensive. Because of extensive wetland loss and the fact that roads occur primarily in upland areas, our roadside surveys included few wetland areas. However, native wetland species are also similarly affected by human land use development (Howe et al. 2007, Peterson and Niemi 2007 this issue). Bird species abundance may also be affected by landscape attributes such as spatial distribution of preferred habitat (Pearson and Niemi 2000) or the amount and type of edge (Hawrot and Niemi 1996). These characteristics are affected by the degree and pattern of habitat loss caused by human development (Medley et al. 1995). The strong correlations between bird abundance and land cover in our study show that the proportion of developed land is a useful metric for detecting variation in species abundance at a regional scale.

In contrast, bird species that use human-dominated land areas have become adapted to the use of human-dominated areas or some have a long history of using these environments. The latter is especially true for species that are invasive (exotic) from Europe such as the rock dove, European starling, and house sparrow. Some native species, such as brownheaded cowbird, common grackle, mourning dove, chimney swift, and ring-billed gull, have more recently adapted to use human-dominated landscapes. Finally, several bird species were found to have little relationship to the disturbance gradient and were commonly found throughout the gradient. These species included black-capped chickadee, American robin, chipping sparrow, and American crow.

While aspects of species and community responses to human development reported in this paper are specific to the coastal regions of western Lake Superior, techniques for evaluating relationships between species relative abundances and landscape development are broadly applicable to other areas. Detrended correspondence analysis was a useful technique for expressing the relationships between land cover and species abundance. DCA was also useful for showing the relationships between species distribution and the disturbance gradient. Monotone regression analysis with the Box-Cox transformation was a valuable, objective tool for detecting species relationships with development. The statistical models calculated for 


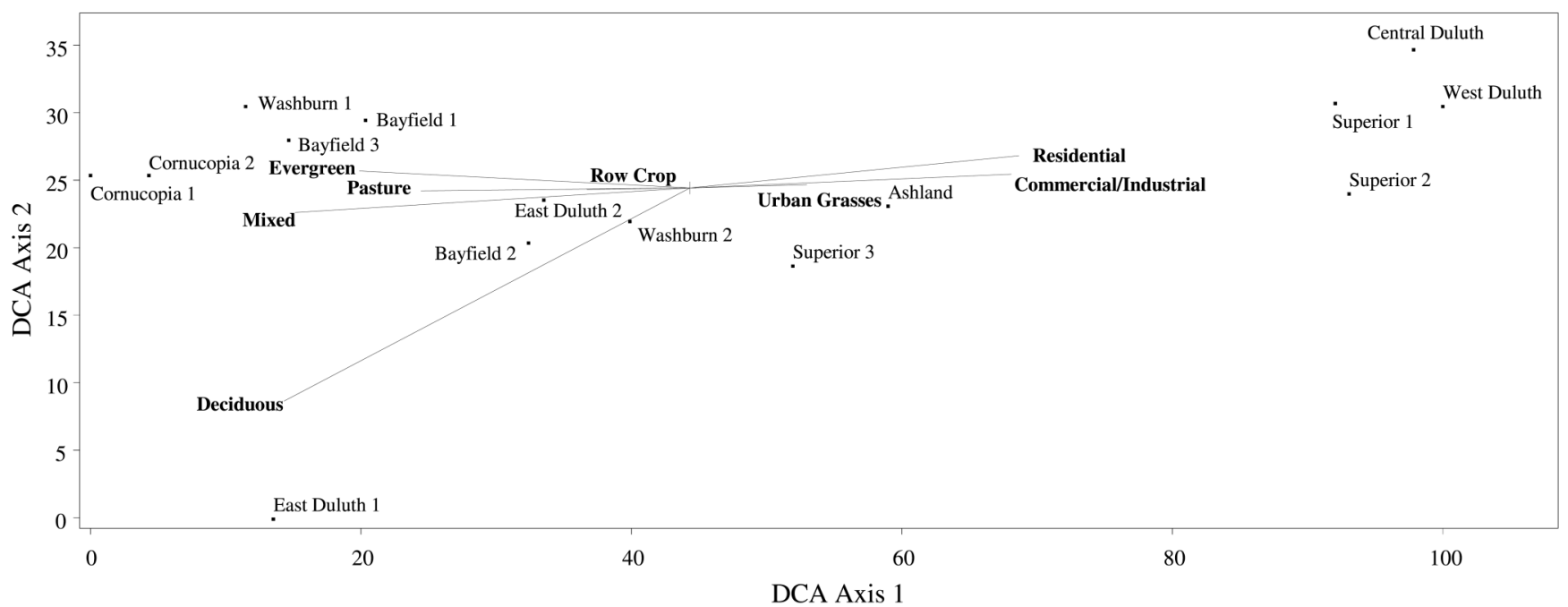

FIG. 6. Detrended correspondence analysis ordination showing study area scores in species space based on characteristics (species composition and abundance) of species assemblages. Radiating lines indicate strength of relationship of land cover to DCA axes in both length and angle.

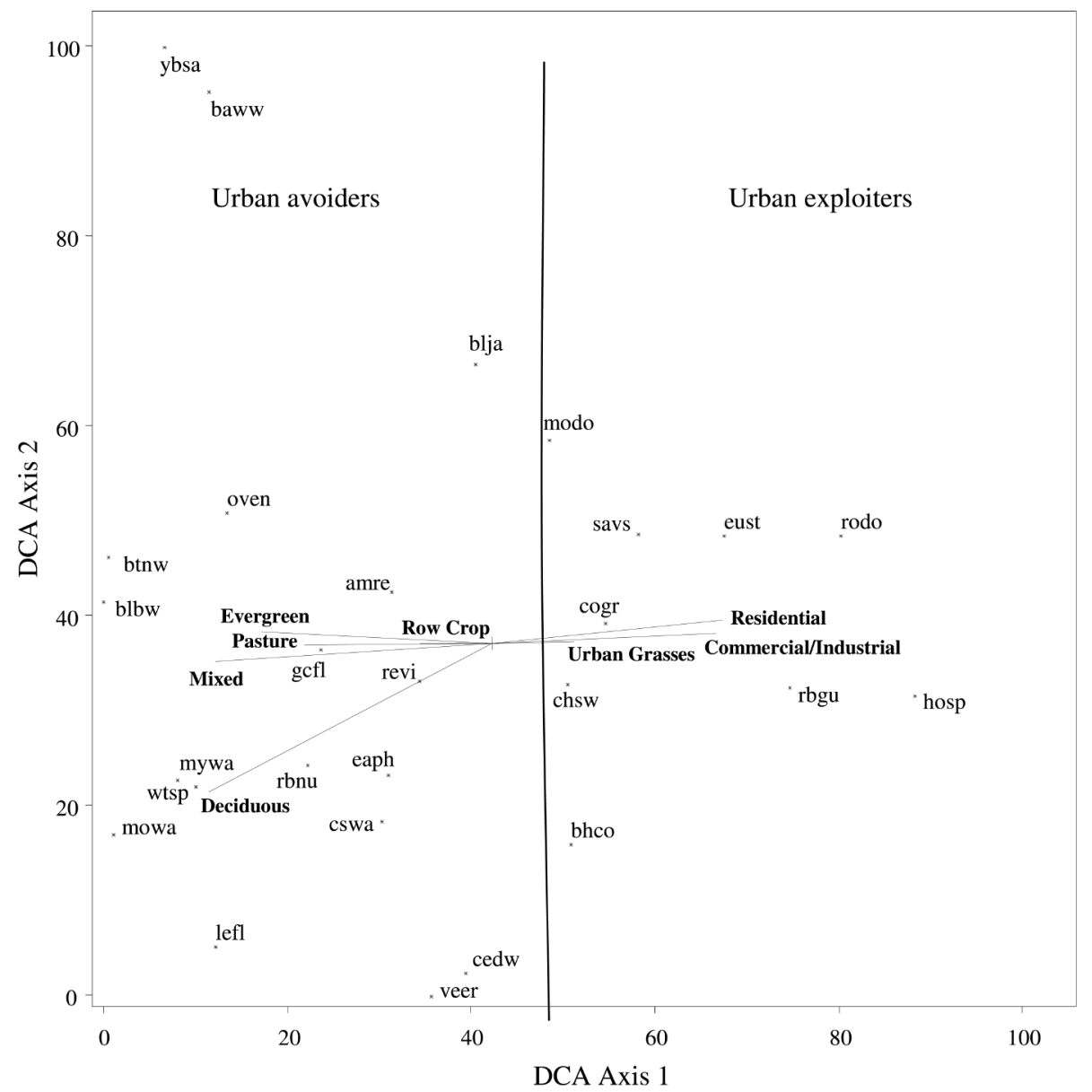

FIG. 7. Species association with development based on relationship to DCA axis 1. Axis 1 closely resembles development gradient based on cover class correlations (see Table 4). 
species with significant regression results $(P<$ $0.05)$ had an excellent fit. In addition, this regression technique indicated that gradient analysis would be a useful metric for explaining variation in the abundance of these species in the coastal regions of the western Great Lakes and possibly for other Great Lakes coastal regions. Detrended correspondence analysis results were consistent with previous studies that report changes in species assemblages, particularly by the decreased abundance of forest-associated species with increased anthropogenic development (Blair 1996, Boren et al. 1999, Allen and O'Connor 2000).

The relationship between bird communities and landscape-scale habitat characteristics has been used to measure and predict ecological condition at local and regional scales (O'Connell et al. 1998, Canterbury et al. 2000, O'Connell et al. 2000). Habitat management for the conservation of forest birds, particularly Neotropical migrants, is an important component of forest management in the western Lake Superior region (Howe et al. 1995). The ability to define thresholds of landscape development where significant changes in community composition or local extinctions among individual species occur would be broadly applicable in both monitoring and planning strategies. Moreover, in an analysis of land cover and land use change in the U.S. Great Lakes watershed from 1992 to 2001, Wolter et al. (2006) found substantial increases in urban, residential area during this relatively short period of time along with substantial decreases in agricultural and forested area. Hence, the recent trend is toward more urban, residential area within this region.

\section{Ecological Indicators and Thresholds}

Birds have been used as excellent indicators of ecological condition and of human-related disturbance (Niemi and McDonald 2004). For instance, birds were among the first indicators of 1) contamination of persistent organic chemicals in the environment (Carson 1962), 2) concerns about the loss of biological diversity due to tropical deforestation (Terborgh 1989), and 3) fragmentation of landscapes (Robbins et al. 1989). Recently, there have been a number of developments in the application of breeding bird communities to understand ecological condition of the environment (O'Connell et al. 2000) and specifically applications in the Great Lakes coastal region (Howe et al. 2007). Breeding bird communities in upland regions are relatively easy to count; measurements such as those used here can be incorporated into ecological indicator analyses and provide an indirect measurement of ecological condition. Direct measurement of ecological condition, in contrast, can be difficult or expensive to measure. Moreover, historical information on land use change, as well as life history characteristics of birds, can potentially be established to diagnose causes of changes in these communities. Further analyses of bird reproduction could also point to other causes of environmental degradation such as localized contamination, disruption of predator-prey relationships, or diseases.

An important component in the development of ecological indicators is to identify thresholds that may lead to collapse in important components of the ecosystem. In the context of this study, if it is an important societal goal to maintain native biological diversity, then landscapes will need to be maintained in such a way to maintain this biological diversity. The results of this study suggest that ecological thresholds at which forest-associated species or "urban avoiders" experience significant declines could be examined by the amount of anthropogenic development in a landscape. Thresholds based on the proportion of developed landscape would be useful in forest bird conservation and regional land planning, especially for residential or agricultural development in the western Great Lakes coastal region. It would be difficult to specify a proportion of the landscape in which the native breeding bird community would be at risk of localized extinction; however, for species such as the ovenbird and black-throated green warbler a reduction to $30 \%$ or less of forested area reduced the probability of observing either of these species. Hence, local extinction of these species is likely. Several others (Robinson et al. 1995) have found similar thresholds of forest habitat loss in agricultural and urban settings and, hence, there is growing evidence that such thresholds may indeed exist. Certainly at some threshold the probability of regional extinction of populations has and will occur.

\section{ACKNOWLEDGMENTS}

We thank Tom Hollenhorst for his help on the GIS portions of this project and Nick Danz for his helpful insights. Funding for data collection was supported by a grant from the U.S. EPA's Science to Achieve Results Estuarine and Great Lakes program through funding to the Great Lakes Environmental Indicators project (U.S. EPA Agreement 
EPA/R-828675). Although the research described in this article has been funded by the U.S. EPA, it has not been subjected to the agency's required peer and policy review and therefore does not necessarily reflect the views of the agency and no official endorsement should be inferred. This is contribution number 469 of the Center for Water and the Environment, Natural Resources Research Institute, University of Minnesota Duluth.

\section{REFERENCES}

Allen, A.P., and O'Connor, R.J. 2000. Interactive effects of land use and other factors on regional bird distributions. J. Biogeogr. 27:889-900.

Ambuel, B., and Temple, S.A. 1982. Songbird populations in southern Wisconsin forests: 1954 and 1979. J. Field Ornithol. 53:149-158.

Blair, R.B. 1996. Land use and avian species diversity along and urban gradient. Ecol. Appl. 6:506-519.

Bolger, D.T., Scott, T.A., and Rotenberry, J.T. 1997. Breeding bird abundance in an urbanizing landscape in coastal southern California. Conserv. Biol. 11:406-421.

Boren, J.C., Engle, D.M., Palmer, M.W., Masters, E., and Criner, T. 1999. Land use change effects on breeding bird community composition. J. Range Manage. 52:420-430.

Canterbury, G.E., Martin, T.E., Petit, D.R., Petit, L.J., and Bradford, D.F. 2000. Bird communities and habitat as ecological indicators of forest condition in regional monitoring. Conserv. Biol. 14:544-558.

Carson, R. 1962. Silent spring. Greenwich, CO: Fawcett Publications Inc.

Cutright, N.J., Harriman, B.R., and Howe, R.W. eds. 2006. Atlas of the breeding birds of Wisconsin. Waukesha, Wisconsin: Wisconsin Society for Ornithology, Inc.

Dowd, C. 1992. Effect of development on bird species composition of two urban forested wetlands in Staten Island, New York. J. Field Ornithol. 63:455-461.

Friesen, L.E., Eagles, P.F.J., and Mackay, R.J. 1995. Effects of residential development on forest-dwelling Neotropical migrant songbirds. Conserv. Biol. 9:1408-1414.

Hanowski, J.M., and Niemi, G.J. 1995. A comparison of on- and off-road bird counts: do you need to go off road to count birds accurately? J. Field Ornithol. 66:469-483.

Hawrot, R.Y., and Niemi, G.J. 1996. Effects of edge type and patch shape on avian communities in a mixed conifer-northern hardwood forest. The Auk 113:586-598.

Howe, R.W., Niemi, G.J., and Probst, J.R. 1995. Management of western Great Lakes forests for the conservation of Neotropical migratory birds. Report to
USDA Forest Service, North Central Forest Experiment Station, Detroit, MI.

, Regal, R.R., Niemi, G.J., Danz, N.P., and Hanowski, J.M. 2007. A probability-based indicator of ecological condition. Ecol. Indic. 7:793-806.

Johnston, C.A., Brown, T.N., Hollenhorst, T.P., Wolter, P., Danz, N.P., and Niemi, G.J. 2007. GIS in support of ecological indicator development. Manual of geographic information systems. Bethesda, MD: American Society for Photogrammetry and Remote Sensing. in press.

Jokimaki, J., and Suhonen, J. 1993. Effects of urbanization on the breeding bird species richness in Finland: a biogeographical comparison. Ornis Fennica 70:71-77.

Kluza, D.A., Griffin, C.R., and DeGraaf, R.M. 2000. Housing developments in rural New England: effects on forest birds. Anim. Conserv. 3:15-26.

Mancke, R.G., and Gavin, T.A. 2000. Breeding bird density in woodlots: effects of depth and buildings at the edges. Ecol. Appl. 10:598-611.

McCune, B., and Mefford, M.J. 1999. PC-ORD. Multivariate analysis of ecological data, version 4. Gleneden Beach, OR: MjM Software Design.

Medley, K.E, McDonnell, M.J., and Pickett, S.A. 1995. Forest landscape structure along an urban-to-rural gradient. Prof. Geogr. 47:159-168.

Niemi, G.J., and McDonald, M. 2004. Application of ecological indicators. Annu. Rev. Ecol. Syst. 35:89-111.

, Lima, A., Hanowski, J.M., and Pfannmuller, L. 1995. Recent trends of breeding birds in Minnesota and Minnesota forested regions. The Loon 67: 191-201.

Wardrop, D., Brooks, R., Anderson, S., Brady, V., Paerl, H., Rakocinski, C., Brouwer, M., Levinson, B., and McDonald, M. 2004. Rationale for a new generation of ecological indicators for coastal waters. Environ. Health Persp. 112:979-986.

Nilon, C.H., Long, C.N., and Zipperer, W.C. 1995. Effects of wildland development on forest bird communities. Landscape Urban Plan. 32:81-92.

O’Connell, T.J., Jackson, L.E., and Brooks, R.P. 1998. A bird community index of biotic integrity for the MidAtlantic highlands. Environ. Monit. Assess. 51:145-156.

, Jackson, L.E., and Brooks, R.P. 2000. Bird guilds as indicators of ecological condition in the Central Appalachians. Ecol. Appl. 10:1706-1721.

Pearson, C.W., and Niemi, G.J. 2000. Effects of withinstand habitat and landscape patterns on avian distribution and abundance in northern Minnesota. In Disturbance in boreal forest ecosystems: human impacts and natural processes, S.G. Conrad, ed., pp. 81-95, USDA Forest Service, North Central Research Station, GTR NC-209. 
Peterson, A.C., and Niemi, G.J. 2007. Evaluation of the Ohio Rapid Assessment Method for wetlands in the western Great Lakes: An analysis using bird communities. J. Great Lakes Res. 33 (Special Issue 3): 280-291.

Pierre, L., Savard, P., Mennechez, C., and Mennechez, G. 2000. Biodiversity concepts and urban ecosystems. Landscape Urban Plan. 48:131-142.

Robbins, C.S., Sauer, J.R., Greenberg, R.S., and Droege, S. 1989. Population declines in North American birds that migrate to the Neotropics. In Proceedings of the National Academy of Science USA 86:7658-7662.

Robinson, S.K., and Robinson, W.D. 2001. Avian nesting success in a selectively harvested north temperate deciduous forest. Conserv. Biol. 15:1763-1771.

, Thompson, F.R. III, Donovan, T.M., Whitehead, D.R., and Faaborg, J. 1995. Regional forest fragmentation and the nesting success of migratory birds. Science 267:1987-1990.

SAS Institute. 1999. SAS/STAT user's guide, version 8. Cary, NC: SAS Institute, Inc.
Temple, S.A., and Cary, J.R. 1988. Modeling dynamics of habitat-interior bird populations in fragmented landscapes. Conserv. Biol. 2:340-347.

Terborgh, J. 1989. Where have all the birds gone? Princeton, New Jersey: Princeton University Press.

Vogelmann, J.E., Howard, S.M., Yang, L., Larson, C.R., Wylie, B.K., and Van Driel, N. 2001. Completion of the 1990s National Land Cover Data Set for the conterminous United States from Landsat Thematic Mapper data and ancillary data sources. Photogramm. Eng. Rem. S. 67:650-652.

Wilcove, D.S. 1985. Nest predation in forest tracts and the decline of migratory songbirds. Ecology 66:1211-1214.

Wolter, P., Niemi, G., and Johnston, C. 2006. Land use change in the U.S. Great Lakes basin 1992-2001. J. Great Lakes Res. 32:607-628.

Submitted: 8 October 2006

Accepted: 30 August 2007

Editorial handling: John R. Kelly 